\title{
MANFAAT MEMPELAJARI ALIRAN \\ ANTROPOLOGI HUKUM
}

\author{
Wenika Cindy Meydia \\ Email : wenikacindy03@gmail.com \\ No BP: 2110003600366 \\ Universitas Eka Sakti Padang
}

\section{A. PENDAHULUAN}

Antropologi adalah sebuah ilmu yang mempelajari makhluk manusia (anthropos). Secara etimologi, antropologi berasal dari kata anthropos yang berarti manusia dan logos yang berarti ilmu. Dalam antropologi, manusia dipandang sebagai sesuatu yang kompleks dari segi fisik, emosi, sosial, dan kebudayaannya. Antropologi melihat hukum hanya sebagai aspek dari kebudayaan, yaitu suatu aspek yang digunakan oleh kekuasaan masyarakat yang teratur dalam mengatur prilaku dari masyarakat, agar tidak terjadi penyimpangan dan penyimpangan yang telah terjadi terhadap norma-norma sosial dapat diperbaiki. Sehingga dapat disumpulkan bahwa antropologi hukum adalah ilmu yang mempelajari prilaku hukum masyarakat, budaya hukum masyarakat, dan cara pandangnya terhadap hukum dan produk-produk turunannya. Hukum-hukum itu bukan hanya yang tertulis dan diundangkan oleh pemerintah, tetapi juga mencakup hukum tidak tertulis yang disepakati masyarakat setempat (adat dan kebiasaan).

Pemikiran-pemikiran antropologi mengarah pada kebutuhan pengembangan teoritis dan praktis (ilmu terapan yang memberi masukan). Menurut Koentjaraningrat dalam bukunya yang berjudul "Pengantar Antropologi I " (1996) menjelaskan bahwa secara akademis, antropologi adalah sebuah ilmu tentang manusia pada umumnya dengan titik fokus kajian pada bentuk fisik, masyarakat dan kebudayaan manusia. Sedangkan secara praktis, antropologi merupakan sebuah ilmu yang mempelajari manusia dalam beragam mausia, suku bangsa, adat serta kebiasaan di dalam masyarakat tersebut. 
Secara awam sering kali dipahami bahwa bidang kajian antropologi adalah masyarakat "primitif", yang dianggap mempunyai kebudayaan yang berbeda dengan kebudayaan masyarakat Eropa. Pemahaman seperti ini tentu saja tidak benar, karena sejauh ini bidang kajian antropologi hukum berkembang memasuki wilayah masyarakat modern. Di lain pihak Masinambow, ed. dalam bukunya yang berjudul "Koentjaraningrat dan Antropologi di Indonesia" (1997) menjelaskan bahwa antropologi adalah disiplin ilmu yang mengkaji masyarakat atau kelompok manusia. Conrad Philip Kottak dalam bukunya berjudul "Anthropology, the Exploration of Human Diversity" (1991) menjelaskan bahwa antropologi mempunyai perspektif yang luas, tidak seperti cara pandang orang pada umumnya, yang menganggap antropologi sebagai ilmu yang mengkaji masyarakat nonindustri. Menurut Kottak, antropologi merupakan studi terhadap semua masyarakat, dari masyarakat yang primitif (ancient) hingga masyarakat modern, dari masyarakat sederhana hingga masyarakat yang kompleks. Bahkan antropologi merupakan studi lintas budaya (komparatif) yang membandingkan kebudayaan satu masyarakat dengan kebudayaan masyarakat lainnya.

Antropologi sebagai kajian antropologis terhadap makna sosial dari pentingnya hukum dengan menelaah bagaimana hukum dibuat dan bagaimana konteks sosial pembuatan hukum tersebut, bagaimana hukum mempertahankan dan mengubah institusi sosial lainnya, serta bagaimana hukum membangun prilaku sosial. Sebagai salah satu cabang ilmu sosial antropologi mempunyai bidang kajian sendiri yang dapat dibedakan dengan ilmu sosial lainnya, seperti sosiologi, ilmu ekonomi, ilmu politik, kriminologi, dan lain-lainnya. Antropologi juga dikelompokkan ke dalam cabang imu humaniora karena kajiannya yang terfokus kepada manusia dan kebudayaannya. Sebagai ilmu sosial yang relatif baru, antropologi juga mengikuti kaidah-kaidah ilmu pengetahuan yang telah berkembang, terutama pendekatan yang berkembang dalam ilmu sosial. Sebagaimana yang telah dijelaskan tentang pengertian dan seluk beluk antropologi, perkembangan dan pemahaman antropologi hukum tentu saja tidak bisa lepas dari aliran-aliran dalam antropologi hukum, bagaimana mempelajarinya dan apa manfaatnya. 


\section{B. PEMBAHASAN}

Perkembangan antropologi hukum selalu dikaitkan dengan kebiasaan masyarakat dan kebudayaan yang berkembang di dalamnya, merujuk kepada tata cara dan nilai-nilai hukum yang berkembang dilingkungan masyarakat itu sendiri. Untuk mengkaji manfaat yang diperoleh dalam mempelajari aliran antropologi hukum, maka harus ada pemahaman tentang macam aliran-aliran yang dipelajari dalam antropologi hukum, yaitu sebagai berikut :

1. Aliran Evolusionisme

Asumsi dasar, kebudayaan mengalami proses perubahan dari satu tahap ketahap selanjutnya secara evolutif.

Tokoh-tokoh yang terkenal :

a) E.B. Taylor : menemukan teori animisme

b) J.J. Bachofen : menemukan teori pembentukan keluarga

c) J.G. Frazer : menemukan teori batas akal dan mugi

d) R.R. Maret : menemukan teori dinamisme

e) Andrew Lang : menemukan teori dewa tertinggi

Kebudayaan dalam perspektif evolusionisme terbagi dalam tiga konsepsi :

a) Kebudayaan sebagai sebuah sistem (cultural system)

Yaitu berupa gagasan, pikiran, konsep, nilai, norma, pandangan hidup, undang-undang, yang dimiliki oleh pemangku ide dan bersifat abstrak

b) Kebudayaan sebagai sistem sosial (cultural universal)

Menurut C. Kluchon kebudayaan sebagainsistem sosial terdiri dari sistem peralatan dan perlengkapan hidup, sistem mata pencaharian, sistem kemasyarakatan,bahasa, kesenian, sistem pengetahuan, dan sisem religi. 
c) Kebudayaan sebagai hasil tingkah laku manusia (material culture)

Terbagi atas benda (artefak) atau material culture dan tingkah laku manusia itu sendiri.

Cara pandang evolusionisme adalah mendeskripsikan unsur-unsur budaya universal dan pola perubahan yang teramati melalui mekanisme pembandingan kebudayaan yang hidup dan berkembang dalam sebuah etnitas budaya.

Adapun ciri-ciri evolusionisme :

- Mempunyai perspektif yang sama, yaitu mengenal perubahan secara perlahan

- Holistuk atau hukum dilihat kaitannya dengan aspek kebudayaan lain

- Tujuan bersifat komparatif

- Tinjauan bersifat universa / hasil kajian berlaju universal secara umum

2. Aliran Kognitif

Asumsi dasar memandang kebudayaan sebagai kognisi manusia atau melihat kaitan antara bahasa, kebudayaan, dan kognisi manusia. Tokoh yang terkenal adalah Ward $\mathrm{H}$. Goodenough.

Kajian antropologi kognitif menjelaskan bagaimana manusia memandang benda, kejadian, dan makna dari dunianya sendiri. Goodenough memandang bahwa kebudayaan bukanlah fenomenamaterial (benda, prilaku, emosi) namun lebih menjadi bagaimana carapengaturan hal-hal tersebut.

Antropologi kognitif terdiri atas dua bahasan yaitu :

a) Bahasa sebagai bahan mentah kebudayaan, kemunculan tiap kebudayaan material dalam kehidupan manusia didahului oleh lahirnya persepsi, naluri, pikiran manusia.

b) Kebudayaan adalah kognisi manusia, seluruh kebudayaan materil yang dihasilkan manusia pada dasarnya hanyalah akibat dari kemampuan pikiran manusia dalam berkreasi. 
Penelitian antropologi kognitif : bahasa + budaya dan kepribadian + budaya menjadi analisis kosa kata dan analisis karakter manusia menjadi perubahan kebudayaaan.

3. Aliran Struktural

Asumsi dasar nalar manusia (human mind) dan sistem relasi (system of relation)

Human mind : kebudayaan dan bahasa berposisi sejajar karena keduanya merupakan hasil nalar manusia.

Tokoh yang terkenal adalah : Claude Levi-Strauss

Tujuan dari kajian antropologi ini adalah menemukan model bahasa dan budaya melalui strukturnya pemahaman terhadap pikiran dan prilaku kehidupan manusia. Sistem relasi dalam antropologi struktural terbagi atas tiga bagian yaitu : relasi manusia dengan kebudayaan, relasi manusia dengan bahasa, dan relasi manusia dengan tradisi.

\section{Aliran Simbolik}

Kebudayaan adalah keseluruhan pengetahuan manusia yang dijadikan sebagai pedoman atau penginterprestasi keseluruhan tindakan manusia. Kebudayaan adalah pedoman bagi masyarakat yang diyakini kebenarannya oleh masyarakat tersebut.

Tokoh yang terkenal adalah : Clifford Geertz

Cara pandang kajian antropologi ini adalah dalam penelitian seorang peneliti harus berdasarkan apa yang diketahui, dirasakan, dan dialami oleh pelaku yang ditelitinya (melihat kenyataan dari sudut pandang pelaku).

5. Aliran Fungsionalisme

Aliran ini muncul sebagai reaksi terhadap pemikiran kaum evolusionis dimana dasar pemikirannya adalah mayarakat dianalisa sebagai bagian-bagian yang terpisahsatu sama lainnya, saling tergantung berdasarkan fungsinya. 
Teori ini memandang masyarakat sebagai sistem yang kompleks yang mana bagian tersebut bekerja sama untuk mempromosikan solidaritas dan stabilitas; ini menandakan kehidupan sosial kita dituntun berdasar pada struktur sosial yang pola prilakunya secara relatif stabil (Macionis, 1997).

Contoh : hukum dalam masyarakat, teorinya tidak lagi bersifat universal tetapi mengenai masyarakat, suku, bangsa, dan desa tunggal. Metode turun ke lapangan dan membuat deskripsi /ekspanasi.

Pemahaman fungsionalistis tentang masyarakat dan kebudayaan harus dituangkan dalam etnografi. Menurut Radcliff Brown fungsionalisme ini merupakan perkembangan dari teori fungsional Durkheim. Fungsi dari setiap kegiatan selalu berulang.

Contoh : penghukuman kejahatan /upacara penguburan adalah merupakan bagian yang dimainkannya dalam kehidupan sosial sebagai keseluruhan dan karena itu merupakan sumbangan yang diberikan bagi pemelihara kelangsungan struktural.

Menurut Bronslaw Malinowski, merintis bentuk rangka teori untuk menganalisa fungsi dari kebudayaan manusia, yaitu sub suatu teori fungsional tentang kebudayaan (Afungsional Theory Of Culture).

Melalui teori ini banyak antropolog menjadikan teori ini sebagai landasan teoritis hingga dekade 1990-an. Kalangan mahasiswa menggunakan teori ini sebagai analisa data skripsi.

Berdasarkan aliran-aliran antropologi hukum yang berkembang dari masa ke masa, mempelajari aliran antropologi hukum mempunyai manfaat yang beragam dalam sistem kehidupan manusia. Manfaat yang diberikan pun tidak terbatas hanya pada pengetahuan saja, tetapi mencakup manfaat teoritis dan manfaat praktis. 
1. Manfaat secara Teoritis

Para teoritis yang dimaksud adalah ilmuan-ilmuan, mahasiswa ilmu-ilmu sosial terutama sarjana ilmu hukum antropologi. Ilmu hukum yang lebih banyak mengabdikan diri untuk kepentingan memajukan ilmu pengetahuan hukum. Beberapa manfaat teoritisnya yaitu sebagai berikut :

a) Dapat mengetahui pengertian-pengertian hukum yang berlaku dalam masyarakat sederhana dan modern.

b) Dapat mengetahui bagaimana masyarakat bisa mempertahankan nilai-nilai dasar yang dimiliki sekaligus mengetahui bagaimana masyarakat bisa melakukan perubahan-perubahan terhadap nilai-nilai dasar tersebut.

c) Dapat mengetahui perbedaan-perbedaan pendapat /pandangan masyarakatatas sesuatu yang seharusnya mereka lakukan.

d) Dapat mengetahui suku bangsa /masyarakat mana yang masih kuat /fanatik mempertahankan keberlakuan nilai-nilai budaya mereka.

2. Manfaat secara Praktis

a) Manfaat praktis hukum

Praktisi hukum yang dimaksud adalah cendikiawan hukum diatas panggung arena hukum di dalam kehidupan masyarakat seperti pembentuk hukum (DPR) pelaksana hukum (pejabat pemerintahan, penegak hukum, polisi, jaksa, hakim). Fungsi praktis dalam bidang hukum adalah untuk membumikan hukum yang sesuai dengan masyarakat tertentu.

b) Manfaat praktis politik

Praktisi politik yang dimaksud adalah aktivis berada yaitu semua yang dalam 
pikiran dan prilakunya berperan dalam era politik, baik yang duduk dalam pelaksanaan pemerintah (penyelenggara negara) mauoun yang berada di luar pemerintahan (lembaga-lembaga politik). Fungsi praktis dalam bidang politik adalah untuk menyeimbangkan pengembangan kebijakan publik/pengambilan keputusan politik dengan hukum yang hidup di masyarakat tertentu.

c) Manfaat praktis masyarakat

Dimaksudkan dengan pergaulan dalam masyarakat bahwa bumi ini bertambah kecil, bukan hanya radio dan televisi yang sudah sampai ke pedesaan tetapi juga telepon melalui jaringan hp yang sudah menjamur sehingga pembicaraan jarak jauh sudah dapat dicapai dalam waktu singkat karena kemajuan teknologi. Fungsi praktis bagi masyarakat adalah untuk memberikan pendidikan hukum bagi masyarakat tentang arti penting, peran serta posisi hukum dalam masyarakat itu sendiri.

\section{PENUTUP}

Antropologi adalah salah satu cabang ilmu pengetahuan yang mempelajari tentang kebudayaaan masyarakat di suatu etnitas tertentu, yang dilihat dari ciri-ciri fisik, adat istiadat, dan kebudayaan yang berbeda. Di dalam perkembangan antropologi, masalah hukum yang dibahas berkenaan dengan masalah yang dihadapi negara-negara berkembang (termasuk Indonesia) yang secara budaya bersifat pluralistis dalam cita-citanya mewujudkan unifikasi hukum atau modernisasi hukum dan berkenaan dengan kemungkinan munculnya masalah bila warga masyarakat dari lingkungan suku bangsa tertentu masih mempunyai norma-norma tradisional yang kuat dan menuntut ketaatan mengenai hal-hal tertentu yang dirumuskan berdasarkan hukum. 
Pemahaman akan antropologi hukum dikaitkan dengan adanya aliran-aliran antropologi hukum yang menjadi bahasan pokok dalam kajian antropologi hukum. Adanya aliran dalam antropologi hukum bertujuan untuk mengelompokkan bagaimana asumsi-asumsi dasar mengenai kebudayaan manusia /masyarakat yang berkembang dari masa ke masa. Menjelaskan bagaimana pandangan para tokoh antropolog, pemahaman manusia, dan bagaimana sistem kebudayaan dalam masyarakat tersebut. Apakah bisa ditelaah dan diamati dengan menggunakan metodemetode yang memang seharusnya digunakan oleh seorang peneliti. Mempelajari aliran antropologi hukum tentu saja tidak terbatas untuk mengetahui apa saja aliran-aliran yang digunakan, siapa tokohnya, dan bagaimana aliran tersebut dapat berkontribusi, beradaptasi serta berkesinambungan dengan kebudayaan masyarakat yang ada. Mempelajari atau memahami aliran antropologi hukum memberikan banyak manfaat khusunya dalam pengembangan kehidupan manusia dan keberagaman kebudayaan masyarakat, tidak sebatas sebagai ilmu pengetahuan yang bersifat materi, namun memberikan pemahaman akan pentingnya keberagaman budaya dan bagaimana sikap dan prilaku yang seharusnya ditanamkan dalam kehidupan pribadi maupun kehidupan masyarakat. Sama halnya dengan manfaat teoritis dan praktis aliran antropologi hukum yang memberikan pemahaman dan pandangan tentang bagaimana sikap dan prilaku individu serta kelompok dalam menyikapi masalah kebudayaan dengan tidak membeda-bedakan kasta dan saling menjaga kebudayaan. Mempelajari antropologi hukum sangat besar peranannya dalam kehidupan manusia, sehingga diharapkan kita untuk selalu mengembangkan wawasan dan memperdalam pengetahuan, pemahaman, serta segala hal yang menyangkut kebudayaan masyarakat yang berkitan dengan antropologi hukum. Dengan kata lain sebagai seorang mahasiswa khususnya dalam hal ilmu-ilmu sosial antropologi hukum sangat berpengaruh. 


\section{DAFTAR PUSTAKA}

Darmini Roza dan Laurensius Arliman S, Peran Pemerintah Daerah Di Dalam Melindungi Hak Anak Di Indonesia, Masalah-Masalah Hukum, Volume 47, Nomor 1, 2018. https://doi.org/10.14710/mmh.47.1.2018.10-21

Laurensius Arliman S, Peranan Metodologi Penelitian Hukum di Dalam Perkembangan Ilmu Hukum di Indonesia, Soumatera Law Review, Volume 1, Nomor 1, 201. http://doi.org/10.22216/soumlaw.v1i1.3346.

Laurensius Arliman S, Peran Badan Permusyawaratan Desa di Dalam Pembangunan Desa dan Pengawasan Keuangan Desa, Padjadjaran Journal of Law, Volume 4, Nomor 3, 2017. https://doi.org/10.15408/jch.v4i2.3433.

Laurensius Arliman S, Penanaman Modal Asing Di Sumatera Barat Berdasarkan UndangUndang Nomor 25 Tahun 2007 Tentang Penanaman Modal, Supremasi Hukum, Volume 1, Nomor 1, 2018. http://dx.doi.org/10.36441/hukum.v1i01.102 .

Laurensius Arliman S, Memperkuat Kearifan Lokal Untuk Menangkal Intoleransi Umat Beragama Di Indonesia, Ensiklopedia of Journal, Volume 1, Nomor 1, 2018, https://doi.org/10.33559/eoj.v1i1.18.

Laurensius Arliman S, Perkawinan Antar Negara Di Indonesia Berdasarkan Hukum Perdata Internasional, Kertha Patrika, Volume 39, Nomor 3, 2017, https://doi.org/10.24843/KP.2017.v39.i03.p03.

Laurensius Arliman S, Partisipasi Masyarakat Di Dalam Pengelolaan Uang Desa PascaUndangUndang Nomor 6 Tahun 2014 Tentang Desa, Jurnal Arena Hukum, Volume 12, Nomor 2, 2019, https://doi.org/10.21776/ub.arenahukum.2019.01202.5.

Laurensius Arliman S, Mewujudkan Penegakan Hukum Yang Baik Di Negara Hukum Indonesia, Dialogica Jurnalica, Volume 11, Nomor 1, 2019, https://doi.org/10.28932/di.v11i1.1831.

Laurensius Arliman S, Mediasi Melalui Pendekatan Mufakat Sebagai Lembaga Alternatif Penyelesaian Sengketa Untuk Mendukung Pembangunan Ekonomi Nasional, UIR Law Review, Volume 2, Nomor 2, 2018, https://doi.org/10.25299/uirlrev.2018.vol2(02).1587

Laurensius Arliman S, Peranan Filsafat Hukum Dalam Perlindungan Hak Anak Yang Berkelanjutan Sebagai Bagian Dari Hak Asasi Manusia, Doctrinal, Volume 1, Nomor 2,2016.

Laurensius Arliman S, Ni Putu Eka Dewi, Protection of Children and Women's Rights in Indonesiathrough International Regulation Ratification, Journal of Innovation, Creativity and Change Volume 15, Nomor 6, 2021.

Laurensius Arliman S, Gagalnya Perlindungan Anak Sebagai Salah Satu Bagian Dari Hak Asasi Manusia Oleh Orang Tua Ditinjau Dari Mazhab Utilitarianisme, Jurnal Yuridis, Volume 3, Nomor 2, 2016, http://dx.doi.org/10.35586/.v3i2.180.

Laurensius Arliman S, Tantangan Pendidikan Kewarganegaraan Pada Revolusi 4.0, Jurnal Ensiklopedia Sosial Review, Volume 2, Nomor 3, 2020. 